\title{
ALKITAB DI DUNIA POSTMODERN
}

\author{
Yunus Selan, M. Mis., \\ Sekolah Tinggi Teologi Pelita Dunia, masyiah@hotmail.com
}

\begin{abstract}
This article talks about the Bible in the Postmodern world. Hopefully this writing or research can help to understand postmodern people assessing and using the Bible.
\end{abstract}

Keywords: Bible, Postmodern

\begin{abstract}
Abstraksi: Artikel ini berbicara tentang Alkitab di dunia Postmodern. Kiranya tulisan atau penelitian ini dapat menolong untuk memahami orang-orang postmodern menilai dan menggunakan Alkitab.

Kata Kunci: Alkitab, Postmodern
\end{abstract}

\section{Pendahuluan}

Alkitab merupakan Firman Allah yang diinspirasikan oleh Roh Kudus kepada manusia dengan menggunakan bahasa manusia (antrofomorfis) supaya melaluinya setiap manusia dapat mengerti dan mengenal kehendak Tuhan sembari menerapkannya dalam tindakan praktisnya setiap hari. Jenis-jenis penerapan menurut Jack Kuhatschek mencakup, "Menerapkan perintahperintah dalam Alkitab, menerapkan kehidupan tokoh-tokoh dalam Alkitab, dan menerapkan janjijanji Alkitab".1 Menerapkan perintah Alkitab berarti memperhatikan hal yang Tuhan perintahkan untuk kita lakukan. Menerapkan kehidupan tokoh-tokoh Alkitab berarti meneladani setiap aspek positif dari kehidupan setiap tokoh Alkitab. Dan menerapkan janji-janji Allah dalam Alkitab berarti mengimani dan mempercayai setiap janji Allah seperti yang dicatat oleh Alkitab melalui kehidupan yang senantiasa berkenan dan mempermuliakan Tuhan.

Alkitab sangat urgen dalam kehidupan orang Kristen (umat manusia), tidak terkecuali bagi mereka yang hidup di dunia postmodern. Hal ini dikarenakan semua yang tercatat dalam Kitab Suci (Kejadian-Wahyu) adalah tentang Anugerah Allah bagi keselamatan manusia. Tanpa Alkitab, orang-orang postmodern tidak akan bisa hidup seperti yang Tuhan kehendaki. Ditambah dengan 
standar hidup orang postmodern yang selalu didasarkan pada kepentingan individu dan tidak melihat Alkitab sebagai sebuah otoritas yang mutlak dan norma yang otoritatif dalam kehidupannya.

Sehingga menjadikan setiap individu sebagai tuhan yang dapat mengambil keputusan sendiri tanpa harus meminta petunjuk dan bimbingan dari Tuhan melalui Alkitab. Itulah sebabnya dalam makalah ini akan dibahas seperti apa posisi Alkitab bagi orang-orang postmodern dan bagaimana Alkitab mempengaruhi atau sebaliknya orang-orang postmodern berusaha mendistorsi prinsip otoritatif dalam Alkitab.

\section{Metode Penelitian}

Penelitian ini menggunakan pendekatan kualitatif, secara khusus kajian pustaka. Pendekatan ini diambil untuk memperoleh pemahaman kualitatif yang valid dan komprehensif bagi topik yang dibahas dalam penelitian ini.

\section{Pembahasan: Latarbelakang dan Situasi Dunia Postmodern}

Dunia postmodern menyangkal keberadaan meta naratif2, sembari percaya setiap orang dapat membentuk "narasi" atau realistisnya masing-masing yang didasarkan pada pengetahuannya sendiri. Pandapat di atas disetujui oleh Jean Francois Lytard seperti komentarnya tentang postmodern pada awal kemunculannya, dengan mengatakan, "Postmodern sebagai ketidakpercayaan terhadap meta narasi".3

Meta narasi yang dimaksudkan di sini adalah Alkitab. Itulah sebabnya, ada empat aspek yang penting dan perlu diketahui untuk memahami situasi dunia postmodern, yaitu: terjadinya dekonstruksi, terdapat relativisme moral yang hendak menegaskan bahwa tidak ada yang mutlak dan pasti, pluralisme yang menegaskan adanya kesederajatan dalam semua agama, dan eksistensialisme, di mana hendak menegaskan bahwa bukan doktrin atau fakta empiris yang diperhitungkan melainkan apa yang saya rasa benar.

Sebagai reaksi dan kritik terhadap modernisme dan lahir sebagai antisipasi semakin lemah dan kompleksnya persoalan ekonomi, sosial, budaya, politik dan seni, maka postmodern berani menerima dan membuka diri terhadap kemungkinan- kemungkinan yang ditolak oleh modernisme. Setiap kemapanan yang dibangun oleh modernisme, dirombak dan disusun kembali dengan wajah yang baru dan ragam yang kuat - disebut oleh Derrida sebagai dekonstruksi.4

2 Meta naratif dalam kekristenan berarti ide atau pandangan bahwa setiap yang terjadi dalam kehidupan setiap individu, terdapat rancangan dan tujuan agung yang bersumber dari Allah dan untuk kemuliaan Allah. Di mana semua informasi dan petunjuknya sudah tertulis di dalam Alkitab.

3 Erroll Hulse, Postmodernisme: Serangan Terhadap Jantung Kekristenan Sejati, (Jakarta: SETIA Press, 2003), hlm.4. $84-86$.

4 Victor E. Taylor dan Charles E. Winquist (Ed.), Encyclopedia of Postmodernisme, (London: Routledge, 2001), hlm. 


\section{Pembahasan: Konsep-konsep Postmodern yang Mendistorsi Prinsip Alkitab}

Seperti yang telah dijelaskan dalam pembahasan sebelumnya, ada empat konsep utama dunia postmodern yang mendistorsi prinsip Alkitab, yakni: dekonstruksi, relativisme, pluralisme, dan eksistensialisme.

Penganut postmodern sepakat bahwa makna dibangun (dikonstruksi) oleh masyarakat melalui media bahasa. Seperti yang dikemukakan oleh Gene Edward Veith Jr., "Deconstructionist agree that meaning is a social construct. Societies construct meaning through language". 5 Bahkan ditambahkan oleh Franz Magnis Suseno, "Mereka menolak paham-paham universal sebagai kediktatoran pemaknaan yang menindas makna-makna nyata masing-masing komunitas"6

Penganut postmodern membangun narasi-narasi kecil dengan mempersempitnya kepada konteks budaya lokal atau setempat yang terlepas dari konteks besar - dalam hal ini konteks Alkitab. Mereka juga menolak otoritas, kewibawaan dan kemutlakan Alkitab. itulah sebabnya meta narasi Alkitab harus didekonstruksi yang selanjutnya direkonstruksi ulang sesuai dengan keinginan masing-masing penafsir.

Selain itu, postmodern juga berpandangan bahwa tidak ada landasan bagi kebenaran yang mutlak, termasuk kebenaran Alkitab. Ketika orang Kristen pada umumnya berbicara tentang halhal yang mutlak dan pasti seperti yang dikemukakan oleh Alkitab (misalnya: kepastian keselamatan melalui Kristus), maka bagi kelompok yang menganut postmodern tetap menganggapnya sebagai sesuatu yang relatif. Mereka juga berpandangan bahwa tidak ada nilainilai yang mutlak, yang berlaku bagi bagi semua orang pada segala waktu. ${ }^{7}$ R. Scott Smith mengatakan, "Postmodern ways of thinking have led us to relize that leaders often are acting to preserve their own power".8 Dengan demikian, pola pikir dan spirit yang coba dibangun oleh postmodern adalah sebuah relativisme.

Selanjutnya adalah pluralisme. Pandangan ini juga hendak meruntuhkan konsep Alkitab yang menegaskan bahwa hanya dalam Kristus-lah ada keselamatan. Sehingga hanya agama Kristen-lah yang dapat membawa setiap manusia berdosa kepada sang Khalik. Makanya tidak mengherankan apabila dunia postmodern begitu menjunjung tinggi yang namanya toleransi. Di mana toleransi menjadi jantung dari pada postmodern. Dengan kata lain, tidak ada agama yang

\footnotetext{
5 Gene Edward Veith Jr., Postmodern Times: A Christian Guide to Contemporary Thought and Culture, (USA: Crossway Books, 1996), hlm. 53.

6 Franz Magnis Suseno, Pijar-pijar Filsafat: Dari Gatholoco ke Filsafat Perempuan, dari Adam Muller ke Postmodernisme, (Yogyakarta: Kanisius, 2005), hlm.

7 Hulse, hlm. 6.

8 R. Scott Smith, Truth and New Kind of Christian: The Emerging Effects of Postmodernism in the Church, (USA: Crossway Books, 2005), hlm. 17.
} 
lebih tinggi atau dianggap memiliki otoritas tertinggi.

Konsep postmodern terakhir yang dibahas dalam makalah ini adalah eksistensialisme. Paham ini mengkampanyekan nilai utama untuk hadir dalam setiap individu, yakni: kebebasan. Meskipun nilai tertingginya adalah otentisitas (keaslian). Dengan demikian, paham ini seolah-olah menempatkan manusia sebagai makhluk yang independen dari Pencipta-Nya atau tidak lagi dependen kepada Tuhan. Konsep ini jelas sangat bertolak belakang dengan prinsip dan ajaran yang termaktub dalam Alkitab.

\section{Hasil: Rancang bangun konsep Alkitab di Era Milenial Dunia Postmodern}

Rancang bangun atau desain bangunan yang didasarkan kepada prinsip dan ajaran dalam Alkitab yang masih dapat dijumpai, secara khusus dalam era milenial di dunia postmodern ini. Misalnya:

Multitasking atau tugas ganda merupakan istilah teknologi informasi yang mengacu kepada sebuah pendekatan atau metode untuk mengerjakan banyak pekerjaan dengan menggunakan sumber daya teknologi. Dengan demikian ungkapan multitasking menggambarkan kemajuan teknologi sebagai karya manusia. Di mana sesuai yang termaktub dalam Alkitab bahwa manusia diciptakan segambar dan serupa dengan Allah, sehingga manusia pun juga mewarisi sifat-sifat Allah yang dapat menjadi creator guna mempermudah dan menolong pekerjaan manusia di bumi.

Inovatif atau reka baru setiap produk guna peningkatan mutu atau kualitas termasuk kemampuan setiap produk yang diciptakan oleh manusia. Hal inipun sekali lagi menunjukkan betapa manusia melakukan setiap tugas atau mandat yang Allah berikan setelah mereka diciptakan. Bahkan prinsip ini pun menunjukkan bahwa manusia memang adalah gambar Allah yang memiliki kemampuan untuk berinovasi. Seringkali inovasi berjalan bersama-sama dengan kreatifitas seseorang, dan kemampuan ini hanya dimiliki oleh manusia - tidak dimiliki oleh makhluk yang lain.

Kerja sama tim berarti dapat membangun kebersamaan dan saling tolong- menolong satu sama lainnya. Kondisi ini hanya akan tercipta apabila ada kasih dan sikap peduli di antara individu. Dalam mewujudkan sebuah kerja sama tim yang efektif, maka diperlukan sikap responsif dari setiap individu yang tergabung di dalamnya. Responsif berarti cepat merespons, menanggapi, tergugah hatinya, dan tidak apatis terhadap kondisi dan situasi yang ada.

Fleksibel berarti mudah dan cepat beradaptasi dengan lingkungan. Menyesuaikan dengan lingkungan bukan berarti sama dengan lingkungan itu. Seperti yang dikemukakan oleh Paulus dalam 1 Korintus 9:20.

Terkahir adalah ambisius. Sikap ini berarti memiliki keinginan yang kuat untuk mencapai sesuatu yang dicita-citakan. Meskipun cenderung negatif, tetapi sebenarnya ini sangat positif dan 
alkitabiah. Karena Alkitab selalu mengajarkan kita untuk terus berjuang, tahan dalam segala pencobaan demi mencapai garis akhir.

\section{Kesimpulan}

Berdasarkan penjelasan panjang-lebar di atas, maka dijumpai bahwa dunia postmodern adalah dunia yang berusaha meruntuhkan (dekonstruksi) otoritas dan kewibawaan Alkitab, dan berujung pada penolakan sifat eksklusif dan kemutlakan dari agama Kristen yang kemudian membuat manusia berusaha independen dan tidak lagi dependen kepada Tuhan dan Juruselamatnya.

\section{Referensi}

Kuhatschek, Jack, Menerapkan Alkitab Di Sepanjang Zaman, Jakarta: Perkantas, 2012.

Hulse, Erroll, Postmodernisme: Serangan Terhadap Jantung Kekristenan Sejati, Jakarta: SETIA Press, 2003.

Taylor Victor E., dan Charles E. Winquist (Ed.), Encyclopedia of Postmodernisme, London: Routledge, 2001.

Veith Jr., Gene Edward, Postmodern Times: A Christian Guide to Contemporary Thought and Culture, USA: Crossway Books, 1996.

Suseno, Franz Magnis, Pijar-pijar Filsafat: Dari Gatholoco ke Filsafat Perempuan, dari Adam Muller ke Postmodernisme, Yogyakarta: Kanisius, 2005.

Smith, R. Scott, Truth and New Kind of Christian: The Emerging Effects of Postmodernism in the Church, USA: Crossway Books, 2005. 